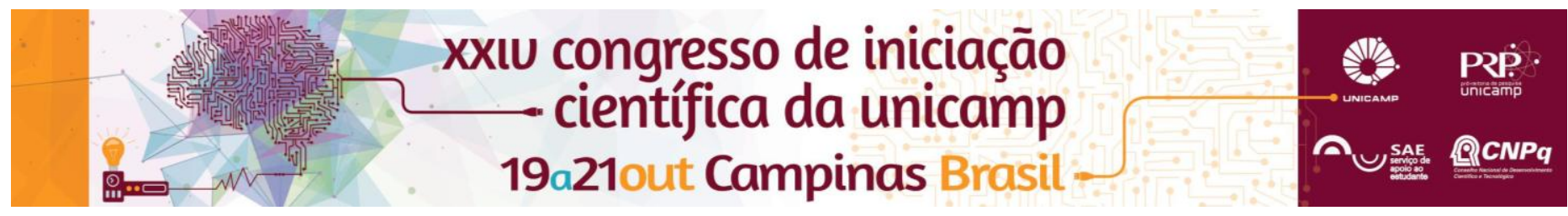

\title{
Os jesuítas no Teto do Mundo: a atividade missionária da Companhia de Jesus no Tibete (1624-1635)
}

\section{Rui Luis Rodrigues, *Franco Alves Biondi}

\section{Resumo}

Dentre os anos de 1624 e 1635, a Companhia de Jesus estabeleceu duas missões em regiões localizadas no atual Tibete, nos então reinos do Gu-gê e de U-Tsang. A partir do relato epistolar dos missionários que participaram das "Missões Tibetanas", procurou-se compreender as estratégias que desenvolveram nessas missões, levando em conta seus contextos políticos e os seus resultados.

\section{Palavras-chave:}

Missões, Jesuítas, Tibete

\section{Introdução}

No ano de 1624, o missionário jesuíta António de Andrade parte de Agra em busca de uma suposta terra de cristãos, conhecida apenas pelos vagos relatos de viajantes e comerciantes muçulmanos. Essa viagem o levará a cidade de Tsaparang, no reino do Gu-gê, onde fundará uma missão. Esse é o início de uma série de tentativas de se criar e consolidar uma comunidade católica no Tibete, que chegará a envolver uma segunda missão, em U-Tsang.

O desenrolar da atuação missionária em uma região tão distinta do universo conhecido pelos jesuítas, assim como 0 isolamento geográfico e linguístico, levará à elaboração de estratégias por parte dos missionários. Percebe-se uma repetição de técnicas já utilizadas em missões anteriores, principalmente as missões no Império do Grão Mogol.

A partir da análise dessas estratégias pelos relatos epistolares dos missionários, propõe-se a formulação de uma interpretação crítica sobre a atuação da Companhia de Jesus no Tibete, levando em conta os esforços despendidos nos dez anos em que duraram as missões e nos resultados praticamente nulos que elas obtiveram.

\section{Resultados e Discussão}

As Missões Tibetanas foram analisadas a partir da compilação de Hugues Didier ${ }^{1}$ que reúne seis cartas relacionadas às missões no Tibete: quatro referentes à missão de Tsaparang e duas, de U-Tsang. O objetivo inicial era propor explicações para a iniciativa de se partir para uma terra desconhecida e de difícil acesso como um resultado de disputas internas da Companhia de Jesus. As informações contidas no corpus documental, juntamente com o tempo disponibilizado para a pesquisa, no entanto, nos levaram a analisar as estratégias adotadas, que refletem as dificuldades encontradas pelos missionários e os limites de suas capacidades de adaptação às situações que encontraram.

As cartas foram analisadas levando em conta seu caráter retórico, como aponta José Eisenberg. ${ }^{2}$ Os moldes das cartas públicas, denominadas hijuelas, condicionam as informações que trazem, ocultando as informações tidas como não dignas de serem conhecidas do grande público, como a aproximação com viajantes muçulmanos ou problemas nas missões. Da mesma forma, as cartas endereçadas aos superiores da Companhia também influenciam o seu conteúdo, a exemplo da situação, quase sempre, excessivamente favorável com que o desenrolar das missões é descrito, o que visa atrair maior apoio e recursos.

A principal estratégia adotada pelos missionários se assemelha fortemente às missões jesuíticas no Império do Grão Mogol, ${ }^{3}$ onde o principal foco foi a conversão dos soberanos. Em Tsaparang, os missionários relacionaram o sucesso da empreitada evangélica ao apoio do rei, assim como a sua conversão. O mesmo objetivo é refletido, mesmo que mais levemente, na missão de U-Tsang.

As dificuldades com a língua local, inúmeras vezes citadas pelos missionários, também colocou limites às suas capacidades de atuação. Isso foi motivo de confusões e incompreensões, tanto dos missionários quanto dos próprios tibetanos, o que, certamente, agiu para o insucesso das missões.

\section{Conclusões}

A dificuldade de compreensão da mensagem evangélica, resultado da barreira linguística, somada à aproximação com o poder real levou os jesuítas para o centro das disputas locais, o que, ambiguamente, serviu para $o$ seu fortalecimento e, ao mesmo tempo, destruição: fortalecimento por encontrarem no poder real um amparo às missões; destruição por se oporem às forças políticas e "religiosas" que acabaram por suplantar o poder representado pelo soberano.

Dessa forma, concluímos que as Missões Tibetanas foram frustradas pelas próprias escolhas dos missionários, assim como pelo contexto histórico do Tibete, que, no momento da chegada da Companhia, encontrava-se em franca ebulição.

\section{Agradecimentos}

Agradeço ao Conselho Nacional de Desenvolvimento Científico e Tecnológico pela oportunidade da pesquisa, efetivada pela bolsa PIBIC. Agradeço também ao meu orientador, prof. Rui Luis Rodrigues, por todo o empenho, auxílio e atenção despendidos na realização desse trabalho.

${ }^{1}$ DIDIER, Hughes. Os Portugueses no Tibete: os primeiros relatos dos jesuítas (1624-1635). $1^{\circ}$ edição. Tradução de Lourdes Júdice. Lisboa: Comissão Nacional para as comemorações dos descobrimentos Portugueses, 2000.

2 EISENBERG, José. As missões jesuíticas e o pensamento político moderno: Encontros culturais, aventuras teóricas. $1^{\circ}$ edição. Editora UFMG, Belo Horizonte - MG, 2000. pp. 27-56.

3 CRUZ, Bruna Dutra de Oliveira Soalheiro. A missão Tibetana na Correspondência Jesuíta (1624-1631). 2009. 140 f. Dissertação (Mestrado em História Social) - Faculdade de Filosofia, Letras e Ciências Humanas, Universidade de São Paulo, São Paulo, 2009. p. 119. 